\title{
Acoustic evolution in crickets: need for phylogenetic study and a reappraisal of signal effectiveness
}

\author{
LAURE DESUTTER-GRANDCOLAS and TONY ROBILLARD \\ Muséum National d'Histoire Naturelle, Département Systématique et Evolution \\ USM601 MNHN \& FRE2695 CNRS, Case Postale 50 (Entomologie), 75231 Paris Cedex 05, France \\ Manuscript received on January 15, 2004; accepted for publication on February 5, 2004.
}

\begin{abstract}
Cricket stridulums and calls are highly stereotyped, except those with greatly modified tegmina and/or venation, or "unusual" frequency, duration and/or intensity. This acoustic diversity remained unsuspected until recently, and current models of acoustic evolution in crickets erroneously consider this clade homogeneous for acoustic features. The few phylogenetic studies analyzing acoustic evolution in crickets demonstrated that acoustic behavior could be particularly labile in some clades. The ensuing pattern for cricket evolution is consequently extremely complex. We argue that: (1) phylogeny should always be considered when analyzing acoustic evolution, whatever characters are considered (signals, stridulums or behaviors). Consequently, future studies should be devoted to entire clades, and not consider isolated taxa; character and character state definitions should allow significant reconstructions of character evolutionary transformations; and homologies should be carefully defined for all characters, including behavior. (2) The factors responsible for song effectiveness should be reconsidered and hypotheses on their potential influence on signal evolution tested jointly by phylogenies (for example, to assess correlated transformations of acoustic and ecological features), and population studies (for example, to correlate call range and population structure, or test the predation risk associated with a signal structure). Better understanding these points should help clarifying acoustic evolution in crickets.
\end{abstract}

Key words: acoustic communication, evolution, phylogeny, calling song effectiveness, crickets.

\section{INTRODUCTION}

Acoustic communication occurs in vertebrates and arthropods, and both groups possess specific organs for the emission and reception of acoustic signals. These organs are constrained by the basic morphoanatomical features of each phylum, and this in turn determines the main characteristics of the signals that each phylum is able to emit (Fletcher 1992). In arthropods, acoustic designs are shaped by the hard exoskeleton, one of the characteristics of this

Correspondence to: Laure Desutter-Grandcolas E-mail: desutter@mnhn.fr phylum. Sound production is most often achieved by stridulation and the emitted sounds are usually considered highly stereotyped compared to those of vertebrates (Dumortier 1963a, Fletcher 1992).

In crickets, the stridulatory apparatus is located on the forewings (FWs), and crickets sing by rubbing their raised FWs together. Sound is produced when the right file hits the left plectrum during FW closure and is radiated by the mechanical resonator made of enlarged areas of both FWs (Michelsen and Nocke 1974, Sismondo 1979). Cricket songs are commonly characterized by their carrier frequency, in- 
tensity and temporal structure (Bennet-Clark 1989). The carrier frequency corresponds to the resonant frequency of the tegminal resonator and the calling song is most often a loud pure tone (Michelsen 1998).

Crickets are usually considered a homogeneous and well-known group and their acoustic evolution has previously been thought to be relatively straightforward, involving limited possibilities of evolutionary changes from an a priori determined ancestral condition (Alexander 1962, Bailey 1991, Otte 1992).

However, recent studies have revealed an unsuspected diversity for all the characters involved in acoustic communication, stridulums, signals and associated behaviors (Huber et al. 1989, DesutterGrandcolas 1995a, 1997a, 1998a, b, PrestonMafham 2000, Bailey et al. 2001, DesutterGrandcolas and Bland 2003), and they brought new information on the behavioral ecology of diverse cricket species not considered to date in current cricket studies and literature. In the same time, phylogenetic analyses have resulted in unexpected evolutionary patterns that contradict current models of cricket acoustic evolution (Desutter-Grandcolas 1997b, c, Huang et al. 2000, Shaw and Herlihy 2000, Desutter-Grandcolas and Robillard 2003, Robillard and Desutter-Grandcolas 2004).

Here we first draw a general picture of cricket acoustic diversity, contrasting for each attribute current ideas with recent discoveries. We then present a short reappraisal of current model for acoustic evolution in crickets. Finally, we present promising cues for cricket evolutionary studies, phylogeny use and effectiveness investigation.

\section{DIVERSITY OF ACOUSTIC FEATURES IN CRICKETS}

\section{Signals}

Only male crickets sing, mostly in the frame of reproduction, and a cricket repertoire may include many different songs (Alexander 1962, Boake 1983, Desutter-Grandcolas 1998c, Su and Rentz 2000). Only calling, the most widespread and the best stud- ied of all cricket songs, is considered here for sake of comparison.

Cricket songs are loud pure tones emitted repeatedly during a limited period of time and characterized by their frequency, amplitude and temporal structure (Bennet-Clark 1999). However, an unsuspected amount of variation (Fig. 1) has been documented.

Cricket calling frequencies usually range between 2 and $8 \mathrm{kHz}$, with one clear dominant frequency corresponding to the resonance frequency of FW resonator (Leroy 1966). Frequency variation may occur in the form of bandwidth, the occurrence of broad modulation, or extreme frequency values. The former parameter has been implicitly acknowledged since a long time, even though its significance in term of signal propagation has not been clarified yet. Only recently have frequencies beyond $12 \mathrm{kHz}$ been recorded in the calls of several Eneopterinae (Desutter-Grandcolas 1997a, 1998a, Robillard and Desutter-Grandcolas in prep.). Further, broad frequency modulations, considered improbable in cricket songs (Alexander 1962, Dumortier 1963b), occurred convergently in eneopterines and phalangopsids (Desutter-Grandcolas 1998a).

Cricket songs are most often very loud (Dumortier 1963b, Leroy 1966, Bennet-Clark 1989). As stated by Alexander (1962, p. 450), "All modern stridulating species - except for a few obviously degenerate species - produce this intense, clear sounds that only crickets among all animals are able to produce with a stridulatory device.' (emphasis ours). However soft calls have been recorded in nemobiines (Bennet-Clark 1989), eneopterines (Desutter-Grandcolas 1997a) and phalangopsids (DesutterGrandcolas 1998b). Calls with amplitude modulation of the carrier frequency (buzzing sounds, Gerhardt 1998), have also been described in hapithine Podoscirtidae (Desutter-Grandcolas and Bland 2003).

Temporal parameters are the most variable features of calling songs. A cricket call commonly comprises pulses (or syllables) that are emitted during each wing closure. The pulses are either emit- 

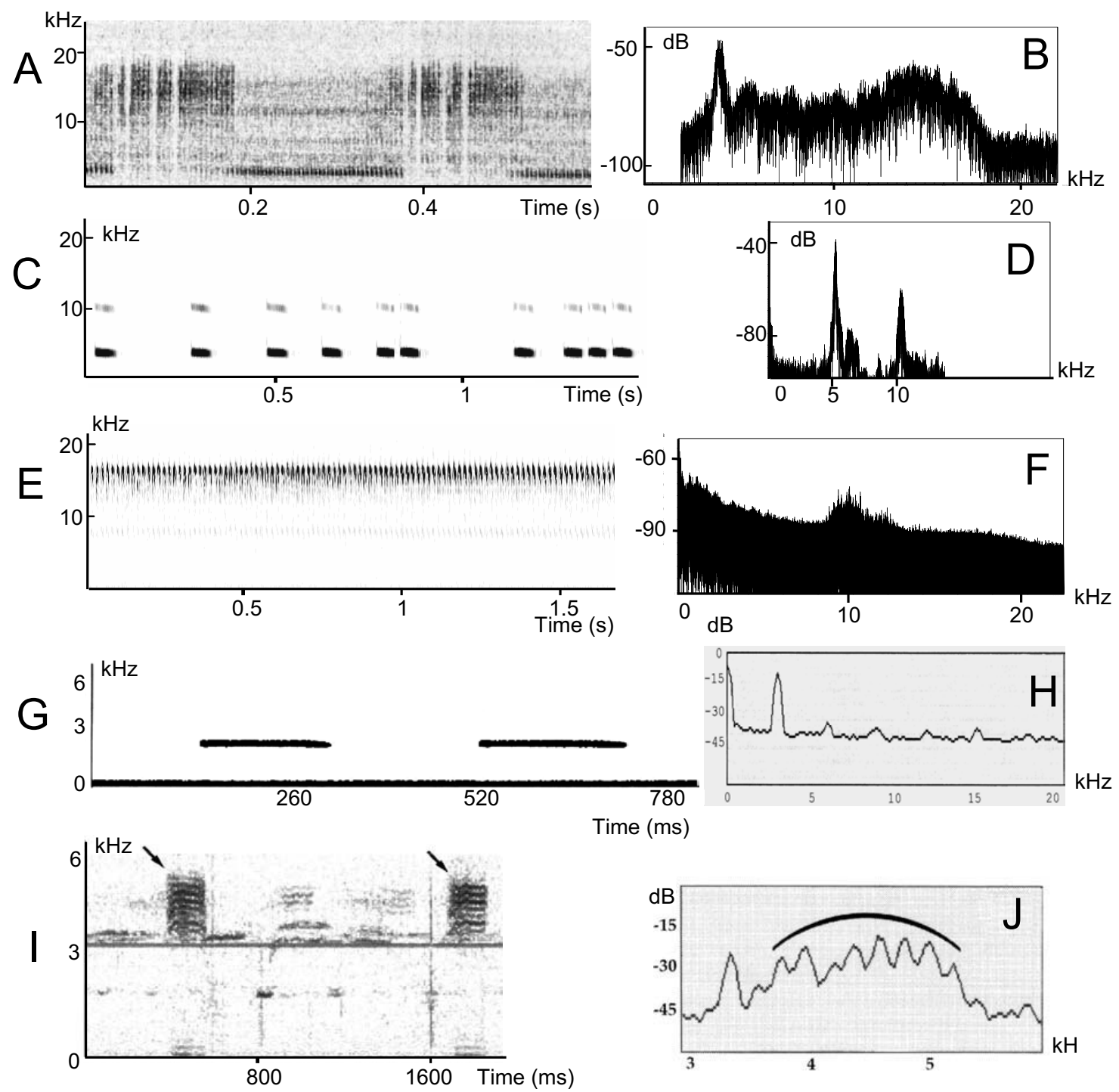

Fig. 1 - Diversity of cricket advertisement signals. Spectrogram and power spectrum of Eneoptera surinamensis (A, B), Xenogryllus marmoratus (C, D), Agnotecous yahoue (E, F), Paragryllodes campanella (G, H) (modified from Desutter-Grandcolas 1998b), and Orocharis fulvescens (I, J) (modified from Desutter-Grandcolas and Bland 2003).

ted continuously (trills) or discontinuously (chirps); chirps in turn vary indefinitely, with regular or irregular pulse period and rate. Maximal impulse duration has been assessed on the basis of efficiency criteria and estimated at less than 50 ms (BennetClark 1989). Similarly, an optimal duration of 30 to $60 \mathrm{~ms}$ has been hypothesized (Otte 1992). However, syllables 3 to 6 times longer are emitted by various cricket species (Desutter-Grandcolas 1998b).
This short enumeration of peculiar features shows that the cricket clade emits more diversified songs than previously thought. It is unclear how this variability affects the song effectiveness.

\section{Cricket Stridulum: Structural AND FunCTIONAL Diversity}

The diversity of cricket stridulum should be analyzed from a structural and a functional point of 
view, because the vibratory properties of a stridulum are directly related to FW morphology and ultrastructure (Michelsen and Nocke 1974). Structurally, a cricket stridulum comprises modified FW structures (file, plectrum) and enlarged areas (harp, mirror, accessory cells). Functionally, it comprises a sound generator, i.e. the file/plectrum mechanism, and an acoustic resonator. All singing crickets generate sounds the same way regardless of the file structure. A huge diversity may exist however for the acoustic resonator based on the following observations. First, tegminal venation may vary greatly among singing species (Fig. 2): the harp is most often present, even reduced, but the mirror area is extremely variable, as shown in Eneopterinae for example (Robillard and Desutter-Grandcolas 2004). Second, FWs may vary greatly for their thickness, especially in phalangopsids (Desutter-Grandcolas 1995a, 1997c): Many species known to emit a calling or at least a courting song possess a thick and stiff right FW. In contrast, others have short, thick and stiff FWs, sometimes with a reduced file.
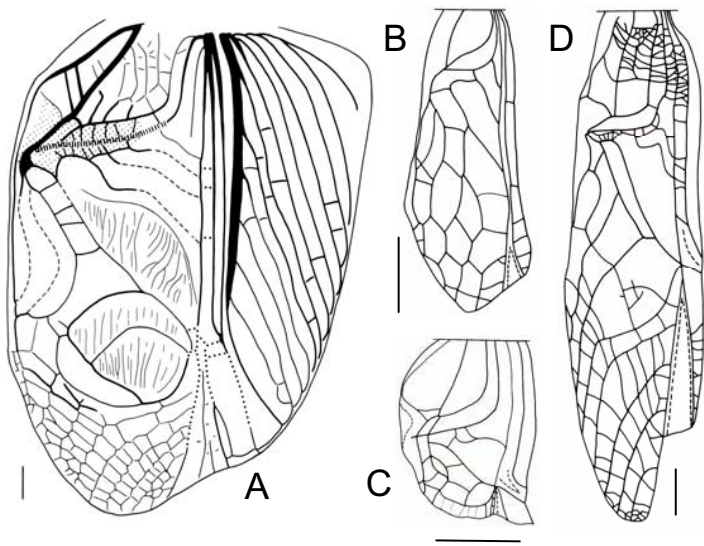

Fig. 2 - Morphological diversity of cricket stridulatory apparatus. Venation of Gryllus campestris (A) (modified from DesutterGrandcolas 1995b), Nisitrus vittatus (B), Agnotecous yahoue (C), and Cardiodactylus canotus (D). Scale bar: $1 \mathrm{~mm}$.

The structural diversity must influence sound radiation, usually achieved by both FWs in crickets, especially in term of resonance properties. Similarly, the harp has been characterized as the acous- tic resonator in Gryllus campestris (Nocke 1971, Michelsen and Nocke 1974), but other radiating cells are known in Oecanthus spp. (Sismondo 1979) or have been hypothesized in modulating species (Desutter-Grandcolas 1998a). A functional shift between FW areas could then occur.

Cricket FW ultrastructure is also diverse (Fig. 3). In insects, wing ultrastructure is commonly analyzed in relation to flight, because it determines flexibility or stiffness and thus delimits unequally deformable areas (Wootton 1981, Brodskiy and Ivanov 1983, Combes and Daniel 2003). Michelsen and Nocke (1974) acknowledged the importance of ultrastructure in acoustics, but this is rarely studied. Yet ultrastructural diversity has been documented for both vein structures and FW surface; it has also been tentatively related to the different, sometimes contradictory, functioning properties acknowledged in cricket stridulums (Desutter-Grandcolas 1995b, 1998a).

\section{PREVIOUS MODEL FOR CRICKET ACOUSTIC EVOLUTION}

Cricket acoustic evolution has been discussed mostly in the frame of ensiferan evolution. Acoustic communication was then considered ancestral to all acoustic Ensifera (Alexander 1962, Bailey 1991, Otte 1992), or was supposed to have appeared independently twice, once in crickets and mole crickets, and once in katydids (Ander 1939). In this general frame, which has been reconsidered recently (Desutter-Grandcolas 2003), diverse hypotheses have been proposed to explain acoustic evolution in crickets.

According to Alexander (1962) and Otte (1992), the tegminal stridulum was perfect from the start, giving "the impression that it involves a mechanism that is difficult to improve upon'" (Otte 1992, p. 25). This idiosyncratic apparatus is associated with an optimal behavioral context, which represents the "acoustic norm" for crickets (Otte 1992). Any deviation from it becomes by definition less effective. For example, stridulatory structures would have evolved mainly by secondary reductions and 

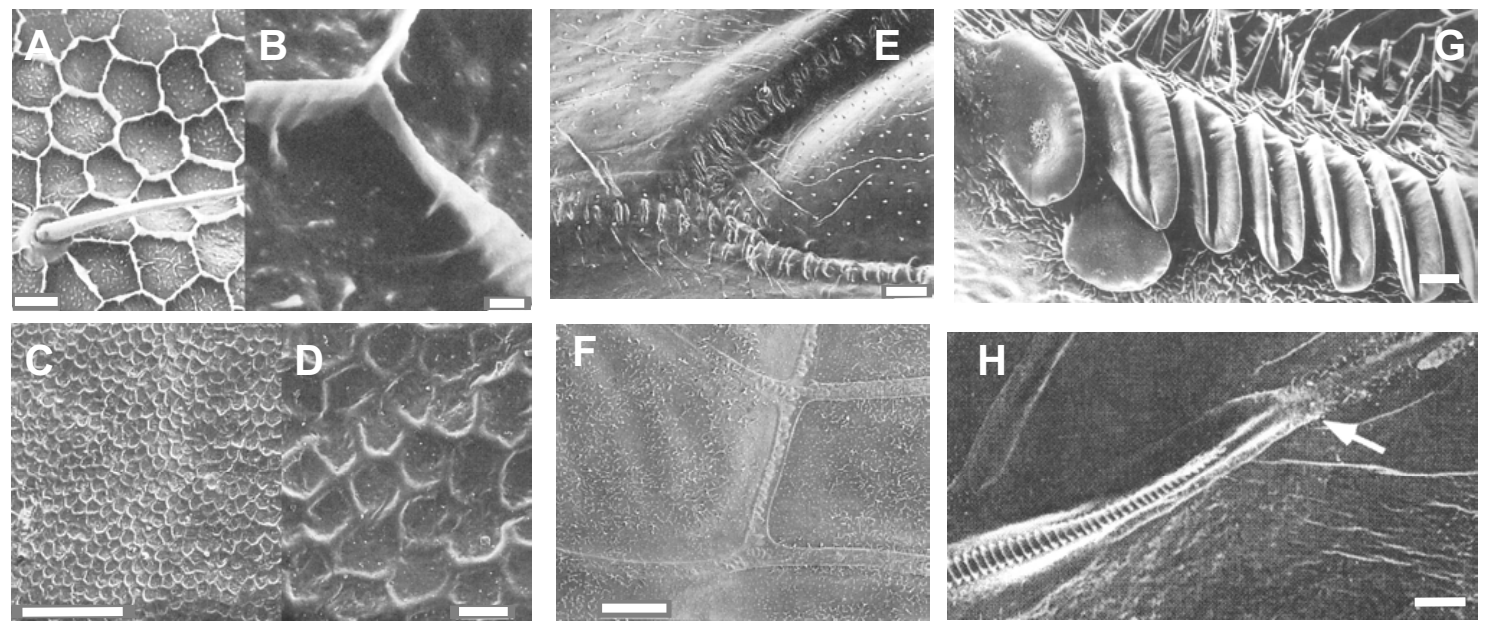

Fig. 3 - Ultrastructural diversity of cricket stridulatory apparatus. Stiff hexagonal relieves in Lerneca fuscipennis (A, B; scales 10 $\mu$ m, $1 \mu \mathrm{m})$ and Oecanthus pellucens (C, D; scales $100 \mu \mathrm{m}, 10 \mu \mathrm{m})$. Annulated vein in O. pellucens (E; scale $100 \mu \mathrm{m})$. Flattened vein in $L$. fuscipennis (F; scale $100 \mu \mathrm{m}$ ). Subdivided file teeth in the modulating species Eneoptera guyanensis (G; scale $10 \mu \mathrm{m}$ ). File swelling in Zvenella yunnana (H; scale $100 \mu \mathrm{m}$ ). Modified from Desutter-Grandcolas (1995b, 1998a) and Ingrisch (1997).

modifications, and experienced multiple and independent losses. Song diversification would have occurred as a response to intra and interspecific interactions under diverse selective pressures (Otte 1992, fig. 11), especially to keep acoustic differences between sympatric species: “...acoustical behavior is one of the slowest kinds of characteristics to change during evolution when it is not required to operate in an environment saturated with similar and potentially confusing signals of similar kinds of animals." (Alexander 1962, p. 461). Patterns of song transformation have been proposed by Alexander (1962, fig. 4) and Otte (1992, fig. 7) and figured as transformational diagrams between song categories or diverse temporal structures respectively. More generally, observations achieved at the population level are directly interpreted as evolutionarily significant. For example, satellite behavior is viewed as an alternative mating strategy reducing predation risk and leading to calling song and stridulum losses (Cade 1980).

Bailey (1991) analyzed further the development of acoustic communication in crickets. According to this author, a "gryllid-blattid" ancestor of modern crickets would have been specialized in a calling behavior by pheromonal communication, lifting its FWs to enhance chemical dispersion. This behavior would have occurred in females, as in modern cockroaches, and would have been at the origin of the calling behavior of male crickets, FW lifting prefiguring the right-left movements of stridulation. A similar idea was developed by Alexander (1987), who wrote: “While crickets and katydids were becoming acoustical, the cockroaches were elaborating chemical and tactual stimuli, and so they remained cockroaches.' (p. 81). This evolutionary switch in communication modalities would be substantiated by the cricket species Phaeophilacris spectrum, whose males lack a stridulum and move their FWs forwards-backwards (instead of laterally) to send air puffs and chemical components to nearby male competitors (Dambach and Lichtenstein 1978, Heidelbach et al. 1991).

How does this general frame explain cricket diversity? Because the ancestral condition has been assumed a complete and functional stridulum and full acoustic communication, the evolution of stridulum and signal cannot be but regressive. There is no place for a hypothesis of phylogenetic diversification. This means that most aspects of cricket acous- 
tic diversity, which are neither predicted nor taken into account, cannot actually be explained. Similarly, calling song divergence was supposed to result from interactions between sympatric species: this also precludes any phyletic evolution. In fact, behavior is considered so highly constrained evolutionarily that behavioral changes are believed to occur only under strong negative pressures arising from interspecific interactions (competition, predation), that could reduce species fitness or lead to extinction.

How can this model be tested? The hypothesis of an ancestral complete stridulum and communication derives from the false idea that "common equals primitive", which has been invalidated since a long time (Watrous and Wheeler 1981, Brooks and McLennan 2002). Similarly, hypotheses of evolutionary changes in acoustic communication in crickets are never characterized by an exclusive pattern of character change. For example, song loss could result from predation pressure (Zuk and Kolluru 1998), sedentarity (Walker 1974), or habitat characteristics (Otte 1992), but there is no way to objectively separate these proposals. In fact, the current model of acoustic evolution in crickets lacks an independent reference to test its proposals: this can be obtained by phylogenetic analyses only.

\section{PHYLOGENY AS A TOOL FOR STUDIES IN ACOUSTIC EVOLUTION}

A phylogenetic hypothesis is a chronicle of evolutionary events (O'Hara 1988) that illustrates character transformation series and allows organizing character diversity into patterns of change (Brooks and McLennan 2002). Historical studies have precise methodological requirements, as follows. 1) Historical studies use phylogenies built for monophyletic entities, and are not based on a few, supposedly more significant, and hence selected, taxa. 2) Historical analyses of character evolution take into account the characters of all the taxa under study, and do not consider only some selected character states. The whole diversity of the clade is thus considered to formulate evolutionary hypothe- ses. 3) Features used in a phylogenetic analysis must be described using accurately defined characters that must be independent and meet usual criteria of homology statements (e.g. Wenzel 1992). This precludes the use of broadly defined characters (e.g. Grandcolas et al. 2001), such as whole song pictures or song categories. 4) No evolutionary hypotheses other than the necessary postulate of “descent, with modification" (Kluge 2001) should influence phylogeny reconstruction (Eldredge and Cracraft 1980). In particular, no ad hoc hypothesis of character transformation should be used for character definition and coding (Deleporte 1993), even a hypothesis of ancestral condition (DesutterGrandcolas et al. 2003). 5) Phylogenetic patterns can be used to test previous hypotheses of evolutionary processes, provided these are first characterized by exclusive patterns of character transformation (Eldredge and Cracraft 1980, Carpenter 1989, Brooks and McLennan 2002). 6) Finally, observations at the population level cannot be extrapolated at a macroevolutionary scale directly. They must be tested for heritability and confronted to a phylogenetic pattern of character change. More generally, evolutionary hypotheses involving differential selective pressures may require a two-step test procedure: first, the predicted pattern of character transformation must be confronted to a phylogeny for corroboration of refutation; second, selective pressures must be contrasted in the populations (Grandcolas and D'Haese 2003). Because selective pressures are not heritable properties but depend on present time environmental conditions, they cannot be optimized on a phylogenetic tree. For acoustics, complementary tests in populations may concern the influence of habitats on emitted signals, predation risk, female preferences or character displacements.

Up to now, few studies have analyzed acoustic evolution of cricket clades in a historical frame. They concern song evolution in North American Gryllus species (Harrison and Bogdanowicz 1995, Huang et al. 2000, Desutter-Grandcolas and Robillard 2003), pattern of speciation in trigonidiine Laupala (Shaw 1996), stridulum evolution in mono- 
phyletic phalangopsid subclades (Desutter-Grandcolas 1993, 1997b, c) and patterns of transformation of stridulum and calling song in Eneopterinae (Robillard and Desutter-Grandcolas 2004).

The current model of acoustic evolution in crickets has been formulated away from a detailed phylogenetic pattern, and proposals that should logically be derived from a phylogeny (e.g. ancestral conditions of stridulum and songs) were drawn from ad hoc hypotheses. Such a narrative frame may support any proposal without any accurate test procedure. In the same way, only few arbitrarily chosen taxa and character states were considered, and the patterns of change described for acoustic behaviors and signals were based on broadly defined characters. This again precludes any test of hypothesized transformational series. Also, the resultant evolutionary hypotheses are not characterized by precise and exclusive patterns of character changes. Song loss for example may result from different selective pressures in different behavioral contexts, and neither can be firmly supported. Finally, because acoustic characters have been selected from the start and their evolution constrained, the model is unable to explain the real diversity of the cricket clade. As an example, the ad hoc hypothesis that Phaeophilacris spectrum could be the necessary missing link between a 'blattid-gryllid' ancestor and modern Ensifera (Bailey 1991) is not supported by phylogeny (Desutter-Grandcolas 2003). The wing movements and communication system of $P$. spectrum are not “primitive'” among crickets in general, and Phalangopsidae in particular, but result from an autapomorphic modification of wing articulation derived from stridulatory wing movements (e.g. Heidelbach and Dambach 1997).

In conclusion, this model is built with too many ad hoc hypotheses and cannot be submitted to usual test procedures of modern evolutionary biology. It should consequently be reformulated, using as a start real diversity of the cricket clade and adequate phylogenetic methods. Studies of ensiferan evolution have been performed in an evolutionary perspective, with (Gwynne 1995) or without (Gorochov 1995) a modern phylogenetic reference. However, they have methodological flaws that limit the significance of their results (Nickle and Nasckrecki 1997, DesutterGrandcolas 2003).

\section{PHYLOGENY AND EFFECTIVENESS REAPPRAISAL}

We will discuss here song evolution in Gryllus species, habitat and song evolution in Amphiacustae crickets and the current definition of calling effectiveness.

\section{Phylogenetic Analysis of Signal Evolution in Gryllus SPecies}

Huang et al. (2000) reconstructed a molecular phylogeny of 9 of the 15 North American Gryllus species (Walker and Moore 2001), and used it to infer the evolution of their calls. In this approach, they classified songs according to Alexander's (1962) categories, defined as combinations of acoustic parameters, and optimized them on one of their two topologies.

Desutter-Grandcolas and Robillard (2003) reconsidered this analysis, especially from a methodological point of view, discussing more specifically the problem of homology statements and character definition for cricket sounds. Several points were then examined: 1) Because cricket songs are heritable features, their analysis in a phylogenetic frame is justified. 2) Because advertisement signals always assume the same function in adult crickets, they can be compared in a historical perspective. 3) Alexander's categories are broadly defined and overlapping, which precludes their use in historical studies. 4) The delineation of characters for call description is far from obvious, because there is no means to identify individually the successive pulses of a song and achieve detailed comparisons between the songs of several species; this situation contrasts with vertebrate signals for example, for which temporal or spectral features can be used as reference marks (Cocroft and Ryan 1995, Bradbury and Vehrencamp 1998, Price and Lanyon 2002). Using homology criteria of position and special quality, Desutter-Grandcolas and Robillard (2003) then 


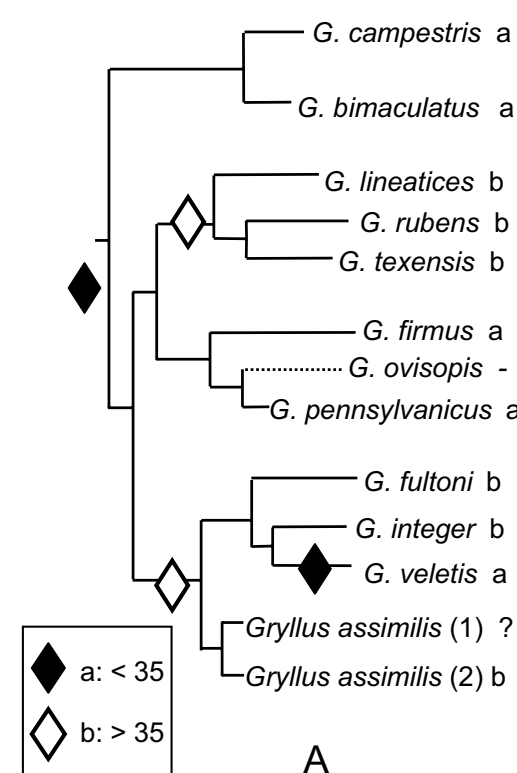

A

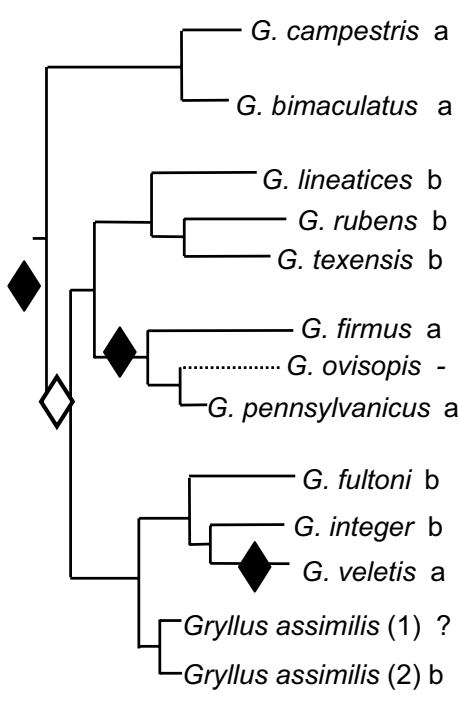

B

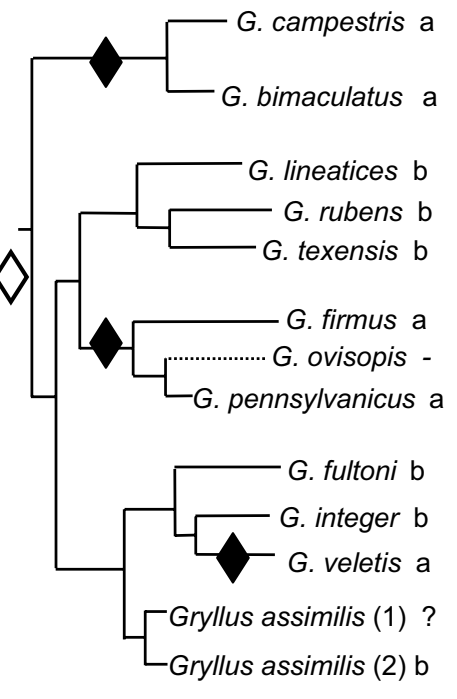

C

Fig. 4 - Evolution of pulse rate in Gryllus song. (A, B, C), alternative equi-parsimonious scenarios. Outgroup taxa not represented. Dotted line: song loss. After Desutter-Grandcolas and Robillard (2003).

defined two different sets of characters, to describe the general structure of the song on one hand, and special properties of identifiable song units on the other.

In the Gryllus case study, the only characters describing song variation concern the pulse rate (PR), chirp rate (CR) and the number of pulses per chirp (PC). Optimizations on a phylogenetic tree show that: 1) song parameters have evolved separately, either simultaneously (i.e. at the same node of the tree) or subsequently; 2) when concurrent changes occur, they concern PC and PR, or PR and PC; 3) reversals may occur for song parameters, especially PR and PC; and 4) a strong evolutionary tendency exists for PC increase.

In this way an ancestral state can be inferred for each studied characters. Comparisons between patterns of character transformation can also check for divergent versus congruent patterns of evolution between acoustic parameters (Fig. 4). Phylogenetic patterns of character change may finally reveal character displacements and allow testing in a second step the potential influence of factors such as habitat, female preferences or phylogenetic inertia.

\section{Habitat and Signal Evolution in Amphiacustae}

Amphiacustae is a monophyletic group of phalangopsid crickets distributed in Central America and in the West Indies (Desutter-Grandcolas 1993). Its phylogeny has been reconstructed from a morphoanatomical data set and used to infer the evolution of habitats, especially cave living, and acoustic communication (Desutter-Grandcolas 1997b, c, d, Desutter-Grandcolas et al. 2003).

Amphiacustae are either troglobitic (Noctivox p.p., Arachnopsita, Longuripes, Prolonguripes, Mayagryllus), or epigean, hiding during the day in cavities at ground level and foraging at night in the leaf litter (all other taxa). According to available phylogenetic reconstructions, Amphiacustae were ancestrally cavicolous and straminicolous; they evolved twice independently toward cave life, in Noctivox p.p. and in the subclade [(Arachnopsita (Longuripes - Prolonguripes)) Mayagryllus], with a subsequent reversal to an epigean way of life in Prolonguripes (Desutter-Grandcolas 1997d).

Acoustic data, still incomplete, are summarized 
TABLE I

Habitat and acoustic characteristics in Amphiacustae crickets. After Desutter-Grandcolas (1993, 1997b, c). Abbreviations: C+S, cavicolous + straminicolous. T: troglobitic.

\begin{tabular}{l|c|c|c|c}
\hline & Habitat & Calling song & Courting song & Aggressive song \\
\hline Amphiacusta & $\mathrm{C}+\mathrm{S}$ & + & + & - \\
Arachnopsita & $\mathrm{T}$ & - & - & - \\
Cantrallia & $\mathrm{C}+\mathrm{S}$ & - & - & - \\
Leptopedetes & $\mathrm{C}+\mathrm{S}$ & - & - & - \\
Longuripes & $\mathrm{T}$ & $?$ & $?$ & $?$ \\
Mayagryllus & $\mathrm{T}$ & $-/ ?$ & $-/ ?$ & $-/ ?$ \\
Nemoricantor & $\mathrm{C}+\mathrm{S}$ & - & + & + \\
Noctivox & $\mathrm{C}+\mathrm{S} / \mathrm{T}$ & + & + & $?$ \\
Prolonguripes & $\mathrm{C}+\mathrm{S}$ & $?$ & $?$ & $?$ \\
\hline
\end{tabular}

in Table I. For calling song, 3 alternative scenarios exist (Desutter-Grandcolas 1997c; Fig. 5): 1) calling song was ancestrally lacking in Amphiacustae and secondarily reacquired in (Amphiacusta (Noctivox - Cantrallia)), with a subsequent reversal in Cantrallia (Fig. 5A); or 2) calling song was ancestrally lacking in Amphiacustae and reacquired twice independently in Amphiacusta and in Noctivox (Fig. 5B); and 3) calling song ancestrally existed in Amphiacustae and was lost twice independently in Cantrallia on one hand, and in [(Leptopedetes Nemoricantor) ((Arachnopsita (Longuripes - Prolonguripes)) Mayagryllus)] on the other (Fig. 5C).

These results show that: 1) habitat is relatively stable in Amphiacustae, while acoustic behavior appears homoplastic. This contradicts previous hypotheses (Alexander 1962); 2) there is no correspondence between habitat evolution and calling properties. In particular, cave living is not obligatorily associated with a lack of calling song, which invalidates previous hypothesis about habitat influence (Otte 1992). None of these evolutionary aspects would have been documented without the phylogenetic background.

Amphiacustae also includes one gregarious species, Nemoricantor mayus, which lives in cavities in Central American rainforest and lacks a calling song (Boake 1983). If cavicoly is not responsi- ble for lacking song, is gregariousness responsible? There may actually be a correlation between habitat and not calling, not because of acoustic properties of habitat, but because calling songs may become ineffective when males and females live in a restricted space (Boake 1983). According to available data, gregariousness (documented in Nemoricantor only) cannot be responsible for the lack of song; but it could be a consequence of lack of song. As a parenthesis, it is worth mentioning that according to available historical analyses Nemoricantor would have reacquired courting and aggressive songs from mute ancestors.

\section{Signal EfFectiveness Reconsidered}

"The effectiveness of a calling signal is determined by the number of sexual partners that respond positively to it." (Alexander et al. 1997, p. 12). Most often, effectiveness of cricket communication is interpreted as the result of pure-tone loudness, signal redundancy and/or tuning of the receiver to call frequency (Römer 1993, Michelsen 1998).

Active increase of signal intensity and range is actually well documented in crickets and results from diverse behaviors (e.g. Forrest 1982) such as perching (Marten et al. 1977, Walker and Whitesell 1982), or baffling (using a substrate, modified or not by the calling male, to increase the surface 


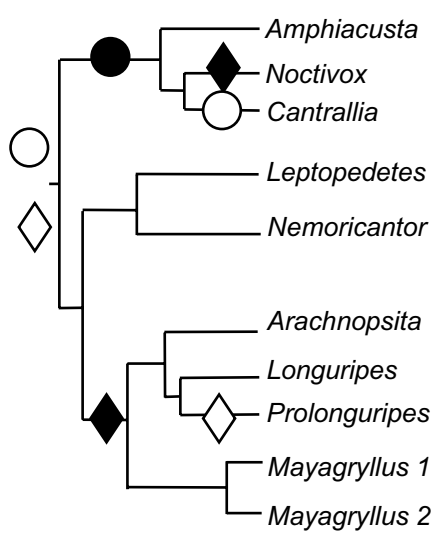

A

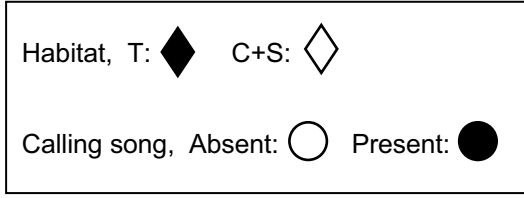

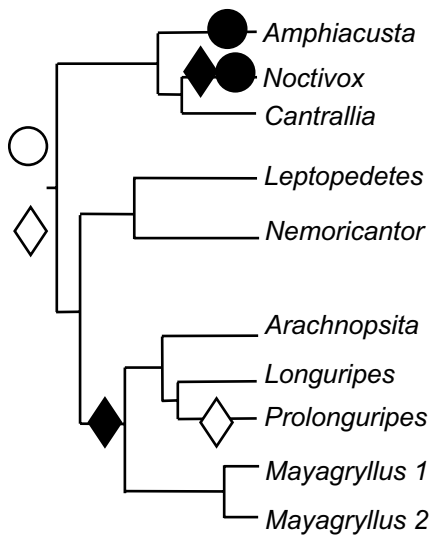

B

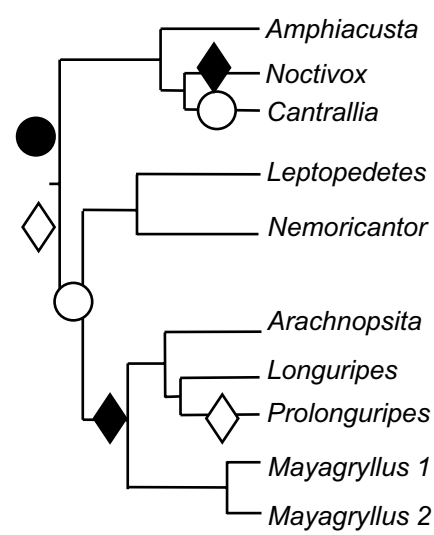

C

Fig. 5 - Evolution of habitats and songs in Amphiacustae crickets. (A, B, C), alternative equi-parsimonious scenarios. Abbreviations: $\mathrm{C}+\mathrm{S}$, cavicolous + straminicolous. T: troglobitic. After Desutter-Grandcolas (1993, 1997b, c).

of the resonator), including using acoustic burrows, documented mostly in mole crickets (Bennet-Clark 1970, but see Bailey et al. 2001).

Observed diversity of signals and stridulums suggests that loudness, redundancy and receiver tuning may not be the only parameters for effective intraspecific communication. For example, how can advertisement calls be effective when they are characterized by low intensity, very-high frequency and/or complex structures? These signals could be rapidly and highly degraded during propagation in their natural environment (Marten et al. 1977, Römer 1993), as shown for birds (Morton 1975, Wiley and Richards 1982, Wiley 1991).

In fact signal effectiveness in crickets may be determined, at least in part, by other parameters than in vertebrates, because of wide discrepancies between them in habitat scale. In a tropical forest for example, some cricket species live in leaf litter only, while others are specialized on low plants, or bushes or canopy leaves; still others forage on tree trunks at night and hide during the day either in holes at ground level or in tree holes and/or under bark up in trees; some are even specialized on lianas, where they forage and from which males sing exclusively (Desutter-Grandcolas 1997e). In these conditions, habitat patchiness and the resultant population structures may be more critical for signal effectiveness than large-scale vegetation. One could then expect a balance between population structure, resulting from habitat characteristics, and signal properties. In fine-scaled habitats, signals have to travel only over a short range to fulfil their calling function.

In fact if one admits that "[i]nsects undoubtedly optimize their signalling strategies", and that " $[t]$ he evolution of signals result from selection to increase their effectiveness in changing the response of receivers"' (Römer 1993), then one should consider the following proposals: 1) An optimal distance may exist in crickets to communicate acoustically, as proposed by Wiley and Richards (1982) for birds, and may be related to population structure in fine-scaled habitats; 2) similarly, a more effective signal may be characterized by an optimal physical 
structure and related to the species habitat and population structure. As a consequence, many different effective contexts may exist in crickets, according to species behavioral ecology, and this may explain the observed diversity of stridulum and signals in this clade.

Habitat and population structure have been considered by previous authors. Walker (1974) associated muteness with sedentariness and tentatively with flightless: species which cannot fly would be more sedentary in permanent habitats and hence would be less dependent on long-range signals. This hypothesis requires however that sedentariness is associated with gregariousness, which is not straightforward. In the same way, Otte (1992) proposed that cave living could lead to muteness, because of bad propagation properties of this habitat. Finally, gregariousness has been associated with song loss, via obligate contacts between males and females (Boake 1983). These hypotheses were proposed however in the frame of song loss hypothesis only.

Finally, acoustic evolution in crickets may be extremely complex, involving several historical patterns such as phylogenetic diversifications, signal losses, reversals and convergences. Thus, acoustic behavior may be highly labile in this clade, contrary to previous hypotheses. In fact, acoustic communication could reveal a key factor for cricket clade diversification. The lability of its components contrasts with the relative stability of habitats, and their combined influence could be the main strength for cricket evolution.

\section{CONCLUSION}

Crickets are a very diverse clade from an acoustic point of view. This diversity for characters directly related to the evolutionary questions under study makes it an interesting model for acoustic studies (Grandcolas et al. 1997).

Crickets live in an environment full of vegetation, conspecifics (both males and females), heterospecifics and potential predators; and calling males are faced with the classical dilemma of gain (mating) and loss (predation, energetic cost) associated with communication (Alexander et al. 1997). Their present-day acoustic features arose in that complex environment and from given ancestral conditions, which both may have shaped acoustic transformations. In turn, the huge diversity observed in crickets for acoustic features mirrors a huge diversity of natural situations that are equally the products of evolution. Deciphering how these situations arose (phylogeny), and how they work (communication effectiveness) is now necessary to propose alternative hypotheses of acoustic evolution in crickets. Acoustic communication may thus be intimately related to clade diversification in crickets. The overall alternative would be that observed diversity for acoustic features has no biological significance.

In order to understand cricket acoustic evolution it will be necessary to use phylogenetic references, taking into account cricket subclades and their diversity for all the traits involved in acoustic communication. Further, signals should not be analyzed in isolation, but instead as one trait of the behavioral ecology of each species: habitats, behaviors and population structures should be characterized in the best possible way for as many taxa as possible.

\section{ACKNOWLEDGMENTS}

This paper has been presented during the XIX International Bioacoustics Congress. We thank J. Vielliard for his help and many useful comments, the organizing committee of the congress for the opportunity to join the IBAC meeting in Belém and anonymous referees for improving the manuscript.

\section{RESUMO}

Os aparelhos estridulatórios e os chamados dos grilos são altamente estereotipados, exceto aqueles com áreas e/ou venação tegminais fortemente modificadas ou com freqüência, duração e/ou intensidade fora do "normal". Esta diversidade acústica ficou insuspeita até recentemente, e os modelos correntes de evolução acústica em grilos consideram erroneamente este clado como homogêneo para as características acústicas. Os poucos estudos filogenéticos 
analisando a evolução acústica em grilos demonstraram que o comportamento sonoro pode ser particularmente lábil em alguns clados. O padrão resultante é conseqüentemente muito complexo. Argüimos que: (1) a filogenia deveria ser levada em consideração sempre que se analisa a evolução acústica, quaisquer que sejam os caracteres examinados (sinais, órgãos estridulatórios ou comportamentos). Portanto, futuros estudos devem abranger clados inteiros e não tratar de táxons isolados; as definições dos caracteres e de seus estados devem permitir reconstruções significativas de suas transformações evolutivas; $\mathrm{e}$ as homologias devem ser cuidadosamente definidas para todos os caracteres, inclusive comportamentais. (2) Os fatores responsáveis para a eficiência do canto devem ser reavaliados e as hipóteses sobre sua influência potencial na evolução dos sinais devem ser testadas em conjunto com análises filogenéticas (por exemplo, avaliar as transformações correlatas de características acústicas e ecológicas) e estudos populacionais (por exemplo, correlacionar alcance do chamado e estrutura populacional, ou testar o risco de predação associado à estrutura do sinal). Uma melhor compreensão desses tópicos ajudaria a esclarecer a evolução acústica nos grilos.

Palavras-chave: comunicação acústica, evolução, filogenia, eficiência do canto de chamado, grilos.

\section{REFERENCES}

AleXANDeR RD. 1962. Evolutionary change in cricket acoustical communication. Evolution 16: 443-467.

ALEXANDER RD. 1987. The evolution of cricket chirps. In: ELDREDGE N. (Ed), The natural history reader in evolution. New York: Columbia University Press, p. 79-86.

Alexander RD, Marshall DC and Cooley JR. 1997. Evolutionary perspectives on insect mating. In: CHOE JC AND CREsPI BJ. (Eds), The evolution of mating systems in insects and arachnids. Cambridge: Cambridge University Press, p. 4-31.

ANDER K. 1939. Vergleichend anatomische und phylogenetische Studien über die Ensifera (Saltatoria) Lund: Berlingska Boktryckeriet.

BAILEY WJ. 1991. Acoustic behaviour of insects. An evolutionary perspective. London: Chapman and Hall.

Bailey WJ, Bennet-Clark HC and Fletcher NH. 2001. Acoustics of a small Australian burrowing cricket: the control of low-frequency pure-tone songs. J exp Biol 204: 2827-2841.
Bennet-Clark HC. 1970. The mechanism and efficiency of sound production in mole crickets. $\mathrm{J}$ exp Biol 52: 619-652.

Bennet-Clark HC. 1989. Songs and the physics of sound production. In: Huber F, Moore TE AND LoHER W. (Eds), Cricket behavior and neurobiology. Ithaca and London: Cornell University Press, p. 227-261.

BenNet-Clark HC. 1999. Resonators in insect sound production: how insects produce loud pure-tone songs. J exp Biol 202: 3347-3357.

BOAKE CRB. 1983. Mating systems and signals in crickets. In: Gwynne DT and Morris GK. (Eds), Orthopteran mating systems. Boulder, Colorado: Westview Press, p. 28-44.

Bradbury JW and Vehrencamp SL. 1998. Principles of animal communication. Sunderland, Massachusetts: Sinauer Associates, Inc.

BrodskiY AK and Ivanov VD. 1983. Functional assessment of wing structure in insects. Entomol Rev 62: $35-52$

Brooks DR and McLennan DA. 2002. The nature of biodiversity. An evolutionary voyage of discovery. Chicago: The University of Chicago Press.

CADE WH. 1980. Alternative male reproductive behaviors. Fla Entomol 63: 30-45.

CARPENTER JM. 1989. Testing scenarios: wasp social behavior. Cladistics 5: 131-144.

Cocroft RB and Ryan MJ. 1995. Patterns of advertisement call evolution in toads and chorus frogs. Anim Behav 49: 283-303.

Combes SA ANd Daniel TL. 2003. Flexural stiffness in insect wings. I. Scaling and the influence of wing venation. J exp Biol 206: 2979-2987.

Dambach M and Lichtenstein L. 1978. Zur Ethologie der afrikanischen Grille Phaeophilacris spectrum Saussure. Zeitschr Tierpsychol 46: 14-29.

Deleporte P. 1993. Characters, attributes and tests of evolutionary scenarios. Cladistics 9: 427-432.

Desutter-Grandcolas L. 1993. The cricket fauna of Chiapanecan caves (Mexico): systematics, phylogeny and the evolution of troglobitic life (Orthoptera, Grylloidea, Phalangopsidae, Luzarinae). Internat J Speleol 22: 1-82.

Desutter-Grandcolas L. 1995a. Toward the knowledge of the evolutionary biology of phalangopsid 
crickets (Orthoptera, Grylloidea, Phalangopsidae): data, questions and scenarios. J Orth Res 4: 163-175.

Desutter-Grandcolas L. 1995b. Functional forewing morphology and stridulation in crickets (Orthoptera, Grylloidea). J Zool Lond 236: 243-252.

Desutter-Grandcolas L. 1997a. Les grillons de Nouvelle-Calédonie (Orthoptères, Grylloidea): espèces et données nouvelles. In: NAJT J AND MATILE L. (Eds), Zoologia Neocaledonica 4, Paris: Mém Mus Natl Hist nat 171, p. 165-177.

Desutter-Grandcolas L. 1997b. A phylogenetic analysis of the evolution of the stridulatory apparatus in True Crickets (Orthoptera, Grylloidea). Cladistics 13: 101-108.

Desutter-Grandcolas L. 1997c. Acoustic communication in crickets (Orthoptera: Grylloidea): a model of regressive evolution revisited using phylogeny. In: GrandCOlas P. (Ed), The origin of biodiversity in insects: phylogenetic tests of evolutionary scenarios. Paris: Mém Mus Natl Hist nat 173, p. 183-202.

Desutter-Grandcolas L. 1997d. Studies in cave life evolution: a rationale for future theoretical developments using phylogenetic inference. J Zool Syst Evol Res 35: 23-31.

Desutter-Grandcolas L. 1997e. Le peuplement de grillons (Orthoptères, Grylloidea) des sous-bois forestiers du Col d'Amieu (Nouvelle-Calédonie). I Etude du peuplement. In: NAJT J AND Matile L. (Eds), Zoologia Neocaledonica 4. Paris: Mém Mus Natl Hist nat 171, p. 125-135.

Desutter-Grandcolas L. 1998a. Broad-frequency modulation in cricket (Orthoptera, Grylloidea) calling songs: two convergent cases and a functional hypothesis. Can J Zool 76: 2148-2163.

Desutter-Grandcolas L. 1998b. Pulse duration and the effectiveness of acoustic communication in crickets (Orthoptera: Grylloidea): the case of Paragryllodes campanella, sp.n. (Phalangopsidae). Ann Soc Entomol Fr (NS) 34: 407-418.

Desutter-GrandColas L. 1998c. First analysis of a disturbance stridulation in crickets, Brachytrupes tropicus (Orthoptera: Grylloidea: Gryllidae). J Insect Behav 11: 149-158.

Desutter-Grandcolas L. 2003. Phylogeny and the evolution of acoustic communication in extant Ensifera (Insecta, Orthoptera). Zool Scr 32: 525-561.
Desutter-Grandcolas L and Bland RG. 2003. New Hapithini (Orthoptera: Grylloidea: Podoscirtidae: Hapithinae) from the Lesser Antilles. Trans Amer Entomol Soc 129: 47-70.

Desutter-Grandcolas L and Robillard T. 2003. Phylogeny and the evolution of calling songs in Gryllus (Insecta, Orthoptera, Gryllidae). Zool Scr 32: 173-183.

Desutter-Grandcolas L, D'Haese C and Robillard T. 2003. The problem of characters susceptible to parallel evolution in phylogenetic analysis: a reply to Marquès and Gnaspini (2001) with emphasis on cave life phenotypic evolution. Cladistics 19: 131-137.

Dumortier B. 1963a. Sound emission apparatus in Arthropoda. In: Busnel R-G. (Ed), Acoustic behaviour in animals. Amsterdam: Elsevier Publish. Co., p. 277-345.

Dumortier B. 1963b. The physical characteristics of sound emissions in Arthropoda. In: Busnel R-G. (Ed), Acoustic behaviour in animals. Amsterdam: Elsevier Publish. Co., p. 346-373.

Eldredge N ANd Cracraft J. 1980. Phylogenetic patterns and the evolutionary process, method and theory in comparative biology. New York: Columbia University Press.

FLeTCHeR NH. 1992. Acoustic systems in biology. New York: Oxford University Press.

Forrest TG. 1982. Acoustic communication and baffling behaviors in crickets. Fla Entomol 65: 33-44.

Gerhardt HC. 1998. Acoustic signals of animals: recording, field measurements, analysis and description. In: Hopp SL, Owren MJ And Evans CS. (Eds), Animal acoustic communication. Sound analysis and research methods. Berlin: Springer, p. 1-25.

Gorochov AV. 1995. System and evolution of the suborder Ensifera (Orthoptera). Parts 1, 2. Proc Zool Inst Rus Acad Sci 260: 3-224, 3-212.

Grandcolas P and D'Haese C. 2003. Testing adaptation with phylogeny: how to account for phylogenetic pattern and selective value together? Zool Scr 32: 483-490.

Grandcolas P, Deleporte P and Desutter-GrandCOLAS L. 1997. Testing evolutionary processes with phylogenetic patterns: test power and test limitations. In: GRANDCOLAS P.(Ed), The origin of biodiversity in insects: phylogenetic tests of evolutionary scenarios. Paris: Mém Mus Natl Hist nat 173, p. 53-71. 
Grandcolas P, Deleporte P, Desutter-Grandcolas L and Daugeron C. 2001. Phylogenetics and ecology: as many characters as possible should be included in the cladistic analysis. Cladistics 17: 104-110.

Gwynne DT. 1995. Phylogeny of the Ensifera (Orthoptera): a hypothesis supporting multiple origins of acoustical signalling, complex spermatophores and maternal care in crickets, katydids and wetas. J Orth Res 4: 203-218.

Harrison RG and Bogdanowicz SM. 1995. Mitochondrial DNA phylogeny of North American field crickets: perspectives on the evolution of life cycles, songs, and habitat associations. J Evol Biol 8: 209-232.

Heidelbach J and Dambach M. 1997. Wing flicking signals in the courtship of the African species Phaeophilacris spectrum. Ethology 103: 827-843.

Heidelbach J, Dambach M and Böнm H. 1991. Processing wing flick-generated air-vortex signals in the African cave cricket Phaeophilacris spectrum. Naturwiss 78: 277-278.

Huang Y, Orti G, Sutherlin M, Duhachek A AND ZERA A. 2000. Phylogenetic relationships of North American field crickets inferred from mitochondrial DNA data. Mol Phyl Evol 17: 48-57.

Huber F, Moore TE and Loher W. 1989. Cricket behavior and neurobiology. Ithaca and London: Cornell University Press.

INGRISCH S. 1997. Taxonomy, stridulation and development of Podoscirtinae from Thailand. Senckenb Biol 77: 47-75.

KLuge AG. 2001. Parsimony with and without scientific justification. Cladistics 17: 199-210.

Leroy Y. 1966. Signaux acoustiques, comportement et systématique de quelques espèces de Gryllides (Orthoptères, Ensifères). Bull Biol Fr Belg 100: 1-134.

Marten K, Quine D and Marler P. 1977. Sound transmission and its significance for animal vocalization. II. Tropical forest habitats. Behav Ecol Sociobiol 2: 291-302.

Michelsen A. 1998. The tuned cricket. News Physiol Sci 13: 32-38.

Michelsen A AND Nocke H. 1974. Biophysical aspects of sound communication in insects. Adv Insect Physiol 10: 247-296.
MorTon ES. 1975. Ecological sources of selection on avian sounds. Amer Nat 109: 17-34.

Nickle DA and Nasckrecki PA. 1997. Recent developments in the systematics of Tettigoniidae and Gryllidae. In: Gangwere SK, Muralirangan MC and Muralirangan M. (Eds), The bionomics of grasshoppers, katydids and their kins. Wallingford, UK: CAB International, p. 41-58.

Nocke H. 1971. Biophysik der Schallerzeugung durch die Vorderflügel der Grillen. Zeitschr Vergleich Physiol 74: 272-314.

O'Hara RJ. 1988. Homage to Clio, or, toward an historical phylosophy for evolutionary biology. Syst Zool 37: $142-155$

OtтE D. 1992. Evolution of cricket songs. J Orth Res 1: 25-49.

Preston-Mafham K. 2000. Diurnal mating behaviour of a Nisitrus sp. cricket (Orthoptera: Gryllidae) from Sumatra. J Nat Hist 34: 2241-2250.

Price JJ And Lanyon SM. 2002. Reconstructing the evolution of complex bird song in the Oropendolas. Evolution 56: 1514-1529.

Robillard T and Desutter-Grandcolas L. 2004. Phylogeny and the modalities of acoustic diversification in extant Eneopterinae crikets (Insecta, Orthoptera, Grylloidea, Eneopteridae). Cladistics: in press.

RÖMER H. 1993. Environmental and biological constraints for the evolution of long-range signalling and hearing in acoustic insects. Phil Trans R Soc Lond B 340: 179-185.

SHAw KL. 1996. Sequential radiations and patterns of speciation in the Hawaiian cricket genus Laupala inferred from DNA sequences. Evolution 50: 237-255.

Shaw KL AND Herlihy DP. 2000. Acoustic preference functions and song variability in the Hawaiian cricket Laupala cerasina. Proc R Soc Lond B 267: 577-584.

Sismondo E. 1979. Stridulation and tegminal resonance in the tree cricket Oecanthus nigricornis (Orthoptera: Gryllidae: Oecanthinae). J comp Physiol A 129: 269-279.

Su YN And Rentz DCF. 2000. Australian nemobiine crickets: behavioral observations and new species of Bobilla Otte and Alexander (Orthoptera: Gryllidae: Nemobiinae). J Orth Res 9: 5-20. 
WALKer TJ. 1974. Character displacement and acoustic insects. Amer Zool 14: 1137-1150.

Walker TJ and Moore TE. 2001. Singing insects of North America. http://buzz.ifas.ufl.edu.

Walker TJ And Whitesell J. 1982. Singing schedules and sites for a tropical burrowing cricket (Anurogryllus muticus). Biotropica 14: 220-227.

Watrous LE and Wheeler QD. 1981. The out-group comparison method of character analysis. Syst Zool 30: $1-11$.

Wenzel JW. 1992. Behavioral homology and phylogeny. Annu Rev Ecol Syst 23: 361-381.
WILEY RH. 1991. Associations of song properties with habitats for terrestrial oscine birds of eastern North America. Amer Nat 138: 973-993.

Wiley RH AND RichaRds DG. 1982. Adaptations for acoustic communication in birds: sound transmission and signal detection. In: Kroodsma DE AND Miller EH. (Eds), Acoustic communication in birds, vol. 1. New York: Academic Press, p. 131-181.

Wootton RJ. 1981. Support and deformability in insect wings. J Zool Lond 193: 447-468.

Zuk M And Kolluru GR. 1998. Exploitation of sexual signals and parasitoids. Quart Rev Biol 73: 415-438. 